\title{
A Glance at the Legal Status of Non-Signatories in International Commercial Arbitration
}

\author{
Yujia Zhang \\ The University of Sydney, Sydney, NSW, Australia \\ Email:mlbsabc@sina.com
}

How to cite this paper: Zhang, Y. J. (2021)

A Glance at the Legal Status of Non-Signatories in International Commercial $\mathrm{Ar}$ bitration. Open Journal of Social Sciences, 9, 269-281.

https://doi.org/10.4236/jss.2021.94021

Received: January 15, 2021

Accepted: April 22, 2021

Published: April 25, 2021

Copyright $\odot 2021$ by author(s) and Scientific Research Publishing Inc. This work is licensed under the Creative Commons Attribution International License (CC BY 4.0).

http://creativecommons.org/licenses/by/4.0/

(c) (i) Open Access

\begin{abstract}
Arbitration has been recognized as one of the most popular ADRs in commercial disputes. Theoretically, arbitration is based on a valid arbitration agreement and only the parties to the agreement are forced to obey the award. However, in legal practice, it is not uncommon for arbitral awards to be enforced against non-signatories. This paper introduces some major legal basis of this situation, including the traditional principles such as agency relationship and other controversial principles, among which "the group of companies" is a typical principle. At the same time, the application of these theories is also discussed. The principle of "group of companies" is considered as a pioneering method specially created for arbitration.
\end{abstract}

Keywords

Arbitration, Arbitral Agreement, Non-Signatory, Enforcement

\section{Introduction}

It has been widely accepted by both domestic and international laws that commercial arbitration is on the basis of consent, under which an arbitration is only binding to the parties of a valid arbitral agreement (Nigel et al., 2015). As is prescribed in both UNCITRAL Model Law and the United Nations Convention on the Recognition and Enforcement of Foreign Arbitral Awards (1958) (New York Convention) (UNCITRAL ML, 1958), an arbitral award can be refused to be recognized or enforceable by the court on account of the incapacity of the parties or the invalidity of the arbitral agreement. In other words, whether a party is bound by an arbitral award firstly depends on if the party is bound by a valid arbitration agreement and if the party is entitled to compel the arbitration clause.

Generally speaking, only the parties who sign the written arbitration agreement are bound by the clauses, pursuant to which is subsequently bound by the 
arbitration award. However, clear guidance in determining what the party of an arbitration agreement is rare in the international conventions or related statutes. As a result, it is usually the discretion of the tribunals or the courts to identify the parties of an agreement and therefore there are some exceptions when such an agreement is valid and enforceable to a non-signatory by virtue of consent according to a varieties of doctrines, including agency, group of companies and subrogation. In addition, there are also theories compelling a third party to be bound by the arbitration agreement despite the lack of consent, most significant one of which is alter ego or veil-piercing. It should be noticed that most of the doctrines are developed from the privity of contract, which is one of the basic principles of contract law and other principles of commercial law (Born, 2014). Most of them have been well accepted by most of the tribunals and courts from different jurisdictions, but some of them are still controversial and not recognized by the authorities in some countries. When applying the admitted principles, the application of the governing law and the onus probandi are two major elements that should be considered by the tribunals and the national courts. In addition, although some of the doctrines are rarely accepted or the adoption of the theories may vary between jurisdictions, it is undeniable that the emphasis of consent, good faith or other fundamental principles of lex mercatoria deserves further consideration.

\section{The Application of Legal Bases for the Non-Signatories Being Bound by the Arbitration Agreement}

As has been pointed out, non-signatories to an arbitration agreement may benefit from or be compelled by such an agreement with the support of varieties of legal bases, with most of them indicate the consent of parties even if they are not in execution of the contract. On the other hand, it is not true with some of other theories when it is the consideration of good faith or equity. The theories discussed below are some significant legal bases which are frequently applied by tribunals and domestic courts when identifying the parties of an arbitration agreement or those which are always discussed in practice.

\section{The Theories on the Basis of Consent}

1) The "group of companies" doctrine

Different from other theories on the consensual base, the "group of companies" doctrine is a theory which is specifically developed for international arbitration in determining the parties of an arbitral agreement notwithstanding the controversies over it. According to the doctrine, a non-signatory company may be entitled to invoke the arbitral clauses or be bound by the agreement where another company in the same group is a party (Kasap, 2017).

It was in France that the doctrine was earlier accepted by the authority through the Dow Chemical case, in which the Dow Chemical Company and its subsidiaries were approved to claim for damages against Isover Saint Gobin by 
ICC, pursuant to the arbitration clauses in the contracts signed in 1965 and 1968 (Dow Chemical France, 1984), although Dow Chemical France and Dow Chemical Company are non-signatories to the agreements. As was pointed out by the tribunal, the Dow Chemical Company was in absolute domination of its subsidiaries, and Dow Chemical France was actively participating in the negotiation of the contract and was the only supplier of the defendant (Kasap, 2017). At the same time, it should be considered that the group of the companies may be in "the same economic reality", and the Dow companies in the group including Dow Chemical France were also sufficiently involved in the execution of the contracts, indicating the intention of being bound by the arbitration clauses in the contracts.

The Dow Chemical case has been subsequently cited as the leading case when applying the "group of companies" doctrine in some awards (Nigel et al., 2015). However, it seems that the rationale which was indicated in the Dow Chemical case has been sometimes expansively interpreted by some awards (ICC Case, 1988), without taking account of the intention of the parties, and as a result, the "group of companies" doctrine may be conflated with veil-piercing theory by misinterpretation (Born, 2014). In fact, as has been pointed out above, it should be born in mind that in most circumstances, a non-signatory is only involved in an arbitration agreement on a consensual basis. As is pointed out by some commentaries, it was because the common intention of the parties rather than the fact that the claimants are in the same group that the Dow Companies were capable to be the parties of the dispute (Gaillard \& Savage, 1999). In addition, the standpoint of the French Court in approving the Dow award was proved to be on the basis of the intention of the parties and therefore the decision was finally concluded from the requirement of consent in an arbitration agreement (Nigel et al., 2015).

As has been mentioned, the doctrine is not adopted by all jurisdictions, in English courts, for example, the parent company and the subsidiary company is strictly distinguished as different legal entities on the basis of law rather than transactions and the doctrine has been expressly rejected by English law (Peterson Farms Inc. v. C\&M Farming Ltd., 2004). At the federal level, in the case of Hancock prospecting Pty Ltd V Rinehart ([2017] FCA 170), the federal court of Australia made it clear that the court should follow the standard of formal review for the initial judicial review of arbitration clauses. In the first trial stage of the case (the first trial case is called Rinehart V Rinehart (NO 3) ([2016] FCA 539)), the judge thinks that there is a seemingly valid arbitration clause, and some disputes involved in the case do fall into the scope of the arbitration clause, but the judge also thinks that the query about the validity of the clause does not fall into the scope of the arbitration clause. In other words, for the initial judicial review of the arbitration clause, the court of first instance adopts a double standard, that is, whether the arbitration clause exists adopts a formal review standard and adopts a substantive review standard for the scope of the ar- 
bitration clause. Similarly, the American authorities have also clearly rejected the existence of the doctrine (Marathan $\mathrm{v}$ Ruhrgas). However, it deserves the attention that the "group of companies" doctrine is presented on the assumption that when entering into the contract, every party hopes to entirely rely on the arbitration clauses in respect to all disputes arising from the agreement which is in line with the basic objective of the international arbitration. And it should also be noticed that no matter how the "group of companies" doctrine is named, the value of the doctrine is that by incorporating the well-developed theories in terms of consent matters, it is designed to adapt to the complex modern transactions between multiple parties (Born, 2014).

2) Agency relationship

Compared with the "group of companies" doctrine, agency relationship could have been widely adopted by authorities under which a non-signatory may be bound by the arbitration agreement in line with the execution of its agent (Born, 2014). For example, as is prescribed in UNIDROIT Principles of International Commercial Contracts, the legal relationship between the principal and a third party will be affected by the act of an agent within the scope of granted authority. As a result, apart from meeting the necessary requirements of a valid arbitration agreement (NYC, 1958), the major problem in enforcing an award against non-signatories according to an agency relationship is to identify whether there is a valid agency relationship between the non-signatory (the principal) and the agent.

In some cases, one party can be always represented by another party without being limited to specific transactions, implying the existence of a general agency relationship. For example, the directors or the officers of a corporate may always execute on behalf of the company. However, in most circumstances, the application of general agency should be cautious, an agency relationship should be established in terms of specified contract and the arbitration clauses in the settlement of the disputes, so that there is sufficient rationale for the principal to be involved in the arbitral agreement. In addition, on the basis of the separability of arbitration agreement, it should be considered that if the agent is authorized with the right to enter into the arbitration clauses, but not merely into the underlying contract. Consequently, when determining the validity of the agency relationship in the establishment of an arbitration agreement, there are two elements should be taken into account including the capacity of the agent and in particular the validity and the content of the agreement in respect to the agency relationship, and accordingly, the application of law governing the two questions mentioned is of significant essence. It should be noticed that the requirements of the form and content to an agency agreement may vary between different domestic laws (Nigel et al., 2015), for example, under Chinese law, an agency relationship should be established in a writing agreement, and it is required by the Austrian authority that a written authorization should be granted to an agent to enter into an arbitral agreement, while according to the decisions in other coun- 
tries including France and Germany, such a form is not required, and as a result, the recognition of the agency relationship may result in different conclusions pursuant to different laws and the non-signatories may fail to compel or be compelled by the arbitral clauses. A distributor and the defendant signed an agency agreement in Australia and chose Hong Kong law as the governing law of the agency agreement. According to the agreement, the agent (plaintiff) will look for buyers in Hong Kong and Southeast Asia to purchase land in Australia. When the agent requested commission, the principal (defendant) claimed that the agent could not obtain the commission because the agent did not obtain the license to act as a real estate agent required by Australian law, and the amount of commission agreed in the agreement exceeded Australia. The maximum limit allowed by law. The party's choice of Hong Kong law as the governing law is invalid because it violates a condition in the principle of "autonomy of will", that is, the parties to the contract cannot resort to fraudulently choosing the governing law of the contract. Since the purpose of the parties in this case is to circumvent the provisions of Australian law on permits and commissions, their choice of Hong Kong law is invalid and Australian law should be applied. Although it has been widely suggested that the law governing the agency agreement should be applied in enforcing the arbitral agreement in this circumstance, what deserves the notice, as is pointed by Born, is the privity of the relationship between the principal and the agent, according to which the applicable laws should be closely related to the parties irrespective of being aware by the counter-party (Born, 2014).

When discussing the agency relationship, apparent authority, another closely related theory should be distinguished from it. Apparent or ostensible authority is also a well-accepted doctrine to bind non-signatories to arbitration agreements. Under apparent authority, a non-signatory may be bound by the act of another party, pursuant to the counter-party has reasonably believed it was conducted by the so-called agent of the non-signatory, despite the lack of real authority (UNIDROIT, 2004). The major different between agency relationship and apparent or ostensible authority is whether the consent matter exists. As has been mentioned, the agency relationship is established on the consent between the principal and the agent, in line with the basic principle of contract law. However, the legal basis for the adoption of apparent authority is more closely to that of estoppel and good faith, in order to protect the right of the relatives in good faith (Born, 2014).

3) Transfers including succession, assignment and subrogation

It is also widely accepted that a non-signatory will become the party of a contract when one of the initial party transfers the contract to the non-signatory and subsequently, the non-signatory will be entitled to claim rights on or be bound by the arbitral provisions in the contract in terms of the settlement of disputes arising from the underlying contract (Hanotiau, 2006). Some common forms of transfers are discussed below. 
The succession always occurs to the combination or the merger of corporations, after which the rights and liabilities of the contracts which was signed by the previous entity will be inherited by the new entity (Born, 2014), and there is generally no doubt that the successor will accordingly become the party of arbitration agreements in the contracts. It is also admitted in Australia (International Arbitration Act 1974) that a successor-in-title can compel the arbitration agreement. At the same time, in some jurisdictions, the principles of succession may extend to a natural person (Born, 2014). However, it is also admitted by authorities that the succession of the arbitration agreement can be precluded. For example, as is prescribed in Interpretation of the Supreme People's Court Concerning Some Issues on Application of the Arbitration Law of the People's Republic of China (People's Republic of China, 2005), the succession of the arbitral clauses are on the basis of consent.

It is commonly accepted that the assignee should automatically bear the rights and obligations in respect of the arbitration pursuant to the assignment of the main contract (Chuprunov, 2012). For example, in France, Germany and UK, this presumption is recognized in some cases (West Tankers Inc. v RAS Riunione Adriatica di Sicurta SpA, 2017). At the same time, in a recent decision of an Australian Court, it has also been pointed out that the party "claiming through or under a party" can be extended to an assignee of a contract (Hancock Prospecting Pty Ltd v Rinehart, 2017). The parties should submit a written notice to disclose the existence and name of the third-party funding. The notice should be sent to the Secretariat immediately when the arbitration request is registered, or when a third-party funding arrangement is reached after registration. However, the parties of the assignment should be granted with the right to decide whether the arbitration agreement is transferred along with the other substantive rights and liabilities in the main contract, in accordance with which, the automatic assignment of the arbitral clauses will be precluded.

There are also some arguments claiming the arbitration agreement will not be transferred automatically together with the contract in which the arbitral clauses are, because the arbitration clauses are independent from the underlying contract for its nature of autonomy and separability (Born, 2014). However, theses presumptions misinterpreted the function of the principle of separability. It should be noticed that the objective of the autonomy of arbitration agreements is to protect the jurisdiction of the tribunals by recognizing the validity of the arbitration agreement when the underlying contract is claimed invalid; if the autonomy is applied to prevent the arbitration, the efficiency of the arbitration will suffer a setback which is contrary to the original intention of the principle (Chuprunov, 2012). As a result, the scope of the application of the autonomy of arbitration agreement should be strictly limited.

In some jurisdictions, it is also suggested that the assignee will not be bound by the arbitration agreement if the bona fide party is not aware of the existence of the arbitration agreement (Nigel et al., 2015). The major reason for such a 
standpoint is to protect the assignee in good faith from suffering the "unpleasant surprise" arising from the arbitration agreement (Chuprunov, 2012). However, it is more appropriate that the assignee bear the risk of the assignment of the arbitration clauses, because compared with the initial party of the contract, the assignee is more probably transfer the burden via the bargain with the assignor (Joseph, 2005). Accordingly, it would be quite unreasonable to damage the rights of the counterparty when protecting the assignee's interests by allowing it escaping from arbitral clauses.

Under the subrogation, the contract rights of a party will be enjoyed by another. The right of subrogation always arises from the relationship between insurer and insured. For example, according to the Insurance Law of the People's Republic of China (People's Republic of China, 2009), the insurer will have the right of subrogation to claim damages.

The issue here is whether the party can subrogate to the rights and obligations in terms of the arbitration clauses automatically. It was affirmed by the Court of Appeals in France that the arbitration clauses should be valid to the insurer, since the rights and obligations over the arbitration clauses are a part of the rights and duties that are enforceable to the insurer pursuant to subrogation (Hanotiau, 2006). At the same time, applying the subrogation to the determination of the parties of an arbitration agreement is critical in protecting the interest of insurer as well as encouraging the insurer to compensate the victim (Hanotiau, 2006).

4) Incorporation by reference

In Thomson-CSF V AAA, incorporation by reference was recognized as a legal base for a non-signatory to be bound by the arbitration agreement. It refers to the circumstances when a non-signatory enter into a contract with a signatory party in which the content of initial agreements are referred. However, in some jurisdictions like England and Wales, only under evident instructions can arbitration clauses be incorporated in the new contract (Luttrell \& Harris, 2016).

In contrast, the attitude towards incorporation by reference in Australia is relatively tolerant. For example, as is pointed out in Carob Industries Pty Ltd (In Liquidation) V Simto Pty Ltd. (2000), the arbitration clause was incorporated into the new contract, according which there is no special requirement in Australia to apply this theory to bind non-signatories to arbitration agreements.

5) Third party beneficiaries

Despite the privity of contract, a third party may have direct rights in a contract if the party has been conferred with the rights and obligation by the signatories of the contract.

And similar to other theories, it critical to identify the intention of parties and the intention of both signatories and non-signatories are important.

When considering the intention of signatories, the separability of arbitration agreement must be taken into account. In other words, what should be identified is whether the signatories intend to grand the rights over arbitration to the third beneficiary or merely confer the substantive rights in the contract (Born, 2014), 
because it can be assumed that the basis for the third beneficiary to enjoy the right over the contract is the common consent of the signatories.

While on the other hand, it is because that the third beneficiary is not the party of the contract that it is not automatically bound by the contract, and accordingly the intention to be bound by the contract also needs consideration. For example, if the third party benefits from the contract between the signatories subject to the authorization of the parties, it might be bound by the arbitral clauses for its implied consent.

6) Implied consent

It is straightforward that any arbitration is formed on the basis of consent. And according to one well-accepted construction of Article 2 of New York Convention (Born, 2014), implied consent may be considered on the absence of express agreement or other legal relationships can support the arbitration. And in practice, tribunals and courts from many jurisdictions have recognised the validity of an implied consent (Hanotiau, 2006).

Consequently, the major issue here is whether an implied consent has been constituted. In addition, despite the difficulty in the application of this theory is the identification of non-signatories, the intention of the signed party to agree to involve the non-signatory into the arbitration is also essential. Generally speaking, the active participation into the execution or negotiation of the contract can support the existence of implied consent, but the occasional participation is not sufficient to constitute a consent. For example, in an ICC case, the implied consent to arbitration was declined since the negotiation between the defendants was "not substantial enough". There are also circumstances in which the implied consent is evident when a non-signatory invokes the arbitral clauses to claim rights or the signatories fail to object such an invocation (Van den Berg, 1997).

\section{The Theories not Applied Consensual Matters}

Although the arbitration depends on the consent of the parties, there are some theories deviating from the consent basis to compel an arbitration agreement to non-signatories, under the consideration of the overriding principle of good faith and equity to protect the order of transactions.

1) The "veil-piercing" doctrine

First applied in U.S. v. Milwaukee Refrigerator Transit Co., it has been admitted by almost all common law and civil law jurisdictions that under the veilpiercing doctrine, a party may be bound by an arbitration agreement if the party constitute an "alter ego" of the signatory of the agreement. Although named diversely by the authorities from different jurisdictions, the "veil-piercing" doctrine is unanimously interpreted as the discharge of corporate personality when a party (a company in most circumstances) is under considerable control of another with some abuse of the power.

As is known, the principle of the independent corporate personality, which was first established in Salomon v. Salomon \& Co. Ltd., has been continuously 
recognized by corporate law, and since alter ego is an exception of such a general legal principle, the application of it by tribunals and courts is always taken with caution, with strict standards to constitute the alter ego established in many jurisdictions (Born, 2014). Even if in the U.S., where the veil-piercing is more easily adopted, it is not easy to meet the criteria. For example, in InterGen $N V V$. Grina, it was emphasized that the independent personality of an entity would be ignored only when it is necessary for the protection of public interest. Accordingly, the key issues in adopting the veil-piercing doctrine are if one party has been strongly dominated by the other, and if a fraud or injustice will be committed under such a domination.

As is stated, although the domination is important, while it is of fundamental importance for the authorities to apply the veil-piercing in an arbitration agreement that a fraud or abuse of right is in existence (Hanotiau, 2006). However, it should be more difficult to decide whether a non-signatory has completely controlled over the signatory, and it is not enough to merely take into account of the superficial "formalities factors" such as the common stock, directors or officers or the "operations factors" including the common subsidiaries and the common business. And as was pointed out by $5^{\text {th }}$ Circuit court, after a brief analysis pf the "financial factors", it was persuasive that the Terkmenneft was dependent on the Government financially because of the financial support of the government and the lack of capital when the company was established, and it was also concluded that undercapitalization was of vital importance in disregard of the personality of corporations. However, even if the doctrine applies on the basis of good faith in many countries, it should be noticed that alter ego analysis is not presented for arbitration and it is because such a misconduct generally occurs in specific transactions when the entities intend to escape from the liabilities that the arbitral clauses in an underlying contract can be binding on the alter ego notwithstanding the separability of an arbitration agreement (Born, 2014).

Another issue deserves the attention is the critical differences between alter ego and the group of companies doctrine. Although it seems that both the theories disregard the personality of companies, the veil-piercing doctrine ignore the intention of entities on the basis of good faith, constituting the rule of law, while the latter is an approach to reveal the real intention of the parties and the legal person status of the company of the group is not denied, which is consistent with the consensual matter of arbitration. And it might be the reason why the application of veil-piercing theory is necessary.

2) Equitable estoppel

A straightforward interpretation of estoppel is that by virtue of good faith and equity, a party may be not allowed to go back on what the party has led another to believe by the statement or actions of the party (Cooke, 2000). It has been accepted as a general principles of international law in particular in common law jurisdictions, and similar concepts such as the "good-intent" doctrine exist (Kasap, 2017), albeit it is claimed to be rarely applied in civil law jurisdictions 
(Hanotiau, 2006). When being invoked to determine the parties of an arbitration agreement, it can be properly explained that a non-signatory may be estopped from denying the arbitration clauses in terms of the disputes arising from the underlying contract. In addition, a very recent decision of the Supreme Court in the U.S. has reaffirmed that this binding a non-signatory to the arbitration agreement does not conflict with the New York Convention. As a result, it is similar to the application of "veil-piercing" theory that the more critical issue in the application of equitable doctrine is not whether the theory should be accepted, but when the theory may be available to the authorities in the recognition and enforcement of an award.

As is pointed by Hanotiau, it is uncommon that the equitable estoppel applies in circumstances when a non-signatory is compelled to be involved in an arbitration. At the same time, it is claimed that it would be more reasonable that a party who signed the arbitration agreement is estopped from it when a nonsignatory intend to invoke the clauses (Born, 2014). For example, in Thomson-CSF, S.A v. Am. Arbitration Association, the order of the District Court in recognition of an award in which Thomson was bound by the arbitration agreement was set aside by $2^{\text {nd }}$ Circuit by virtue of the rationale that "there is no indication that Thomson was willing to be bound by the arbitration agreement and the court was not entitled to estop the company from the clauses because of the lack of consent, which is the nature of arbitration. Nonetheless, as is concluded in InterGen $N V$ v. Grina, a party should abide by the clauses which are against to it when the party has benefited from other provisions in the same contract. Consequently, it might be inappropriate that the estoppel theory cannot apply equally to signatories when they attempt to rely on the arbitration agreement to resolve the disputes against non-signatories. And as is stated by Born, some US courts have made decisions in favour of the signatories to enforce the award to the non-signatories.

The controversies arising from the application of equitable estoppel also include applicable law to estoppel as well as the standard of proof. Although it has been suggested that international principles of estoppel and good faith may be a better option, authorities have their own construction in the choice of the law, under which the application of equitable estoppel or the proof standard may vary according to the governing law (IMC v Altain Khuder, 2011). At the same time, it has been pointed out in a judgement of Supreme Court of Victoria that failing to object the jurisdiction or challenge the award in the court where the seat was could not constitute the grounds for estoppel and more substantive evidence should be provided to support the application of estoppel. Although the decision is under controversy for the distribution of burden of proof (Winter, 2015), it can be concluded from the case that when applying estoppel doctrines, the first issue to be considered is the reasonableness that a non-signatory is not involved in the underlying contract, but not the participation of the party. And what should be bear in mind subsequently is if the conduct of the non-signatory has reasonably 
be relied by the signatory (Waincymer, 2012).

\section{A Summary to the Application of the Theories}

As has been discussed above, the attitude towards the theories supporting the efficiency of arbitration agreements to non-signatories may vary between different jurisdictions, and even if completely accepted by the authorities, it is still possible that an award may not be recognized or enforced due to the diversity of applicable laws and criteria of proof (IMC v Altain Khuder, 2011).

Compared to the traditional consensual theories including agency, implied consent and successions or the theories such as veil-piercing and estoppel which are developed from good faith and justice, the "group of company" doctrine is regarded as a pioneer approach created particularly for arbitration, and consequently, when being applied to identify the parties of arbitration agreements in the enforcement of awards, it bears more risks in the adoption of it.

In Australia, it is reported that most foreign award seeking enforcement has been approved and at the same time, the fact that a non-signatory is eligible to rely on or obliged to an arbitration agreement in the recognition and enforcement of an arbitration award has been affirmed in the International Arbitration Act via the statement of "a person claiming through or under a party" (Pryles, 2018). Although it is a common sense that arbitration is the scope of the notion of "claiming through or under a party" included theories on the consensual basis, a recent judgement of High Court of Australia has also implied that the estoppel theory is possible to apply to the scope of the party prescribed in IAA (Rinehart v Hancock Prospecting Pty Ltd., 2019).

Unlike single state, Australia has federal and local distinction between the jurisdiction of arbitration. International arbitration is generally governed by the Federal International Arbitration Law. The law includes the provisions of the UNCITRAL Model Law, the New York Convention and the Washington Convention into its norms, which has a relatively loose management standard for international arbitration. The parties may also choose to exclude the application of the Federal International Arbitration Law, so that the corresponding arbitration will be governed by the Commercial Arbitration Law of the Australian states/territories. In the specific arbitration process, ACICA can provide the necessary convenience and help for the arbitration process, including reasonable hearing place, secretarial assistance and translation services. ACICA can also appoint or recommend experienced arbitrators, recommend other experienced arbitrators, determine arbitration fees and retain necessary arbitration deposit.

In conclusion, irrespective of how the theories which bind a non-signatory to an arbitration agreement is adopted by authorities, one thing can be determined is as basic principles of contract law, both consent and good faith should be taken into consideration. It seems that there are still many judgements in dispute, it is not easy in practice, however, to combine the complex legal bases departing from contract law with the distinctive nature of arbitration such as 
autonomy. From this perspective, the establishment of doctrines specifically applied to arbitrations may be helpful but rather difficult. On the other hand, although the analysis of the theories should be on a case by case basis (Born, 2014), what should be born in mind is the first objective to accept different doctrines in arbitration is to support the enforcement of awards to keep consistent with the notion that arbitration is an effective alternative dispute Resolution.

\section{Conflicts of Interest}

The author declares no conflicts of interest regarding the publication of this paper.

\section{References}

Born, G. B. (2014). International Commercial Arbitration (2nd ed.). Alphen aan den Rijn: Kluwer Law International.

Carob Industries Pty Ltd. (In Liquidation) v Simto Pty Ltd. (2000). 23 WAR 515.

Chuprunov, I. S. (2012). Chapter I: The Arbitration Agreement and Arbitrability: Effects of Contractual Assignment on an Arbitration Clause-Substantive and Private International Law Perspectives. In C. Klausegger, P. et al. (Eds.), Austrian Yearbook on International Arbitration. Manz'sche Verlags-und Universitätsbuchhandlung.

Cooke, E. (2000). The Modern Law of Estoppel. Oxford: Oxford University Press. https://doi.org/10.1093/acprof:oso/9780198262220.001.0001

Dow Chemical France (1984). The Dow Chemical Company and Others v ISOVER Saint Gobain, Interim Award, ICC Case No. 4131, 23 September 1982, in Pieter Sanders (ed.), Yearbook Commercial Arbitration 1984-Volume IX ICCA \& Kluwer Law International, 131, 136-137.

Gaillard, E., \& Savage, J. (Eds.) (1999). Part 2: Chapter II-Formation of the Arbitration Agreement. In: Fouchard Gaillard Goldman on International Commercial Arbitration. Kluwer Law International.

Hanotiau, B. (2006). Complex Arbitrations: Multiparty, Multicontract, Multi-Issue and Class Actions. Alphen aan den Rijn: Kluwer Law International.

Hancock Prospecting Pty Ltd v Rinehart (2017). 257 FCR 442; 350 ALR 658; FCAFC 170; BC201709114.

IMC Aviation Solutions Pty Ltd v Altain Khuder LLC [2011] VSCA 248 InterGen NV v. Grina, 344 F.3d 134, 148.

InterGen N.V. v. Grina, 344 F.3d 134.

International Arbitration Act 1974 (Cth).

Joseph, D. (2005). Jurisdiction and Arbitration Agreements and Their Enforcement (3rd ed.). London: Sweet \& Maxwell.

Kasap, G. H. (2017). Etching the Borders of Arbitration Agreement: The Group of Companies Doctrine in International Commercial Arbitration under the U.S. and Turkish Law. University of Bologna Law Review, 2, 87-113.

Luttrell, S. P. L., \& Harris, P. (2016). Variations on a Theme: Common Law Approaches to the Incorporation of Arbitration Clauses. The ACICA Review, 4, 13.

Nigel, B., Partasides, C. et al. (2015). Redfern and Hunter on International Arbitration (6th ed.). Oxford: Oxford University Press.

New York Convention (NYC) (1958). Art II (2). 
People's Republic of China (2005). Interpretation of the Supreme People's Court Concerning Some Issues on Application of the Arbitration Law of the People's Republic of China. Supreme People's Court, Fa Shi No. 7, 26 December 2005.

People's Republic of China (2009). Insurance Law of the People's Republic of China. National People's Congress, Order No. 11, 8 February 2009.

Pryles, M. (2018). National Report for Australia. In L. Bosman (Ed.), ICCA International Handbook on Commercial Arbitration. ICCA \& Kluwer Law International.

Rinehart v Hancock Prospecting Pty Ltd. (2019) 366 ALR 635.

Thomson-CSF, SA v. Am. Arbitration Ass' n, 64 F.3d 773, 776.

Peterson Farms Inc. v. C\&M Farming Ltd. (2004). Arbitration Law Reports and Review, 2004, 573-585. https://doi.org/10.1093/alrr/2004.1.573

UNCITRAL Model Law on International Commercial Arbitration, 1985, with amendments as adopted in 2006. Vienna: United Nations, 2008.

United Nations Convention on the Recognition and Enforcement of Foreign Arbitral Awards. New York, 10 June 1958.

UNIDROIT (2004). Principles of International Commercial Contracts. Art. 2.2.5.

Van den Berg, A. J. (Ed.) (1997). Agent v Principal and Managing director of principal, Final Award, ICC Case No. 7453, 1994. In Yearbook Commercial Arbitration 1997. ICCA \& Kluwer Law International.

Waincymer, J. M. (2012). Procedure and Evidence in International Arbitration. Alphen aan den Rijn: Kluwer Law International.

West Tankers Inc. v RAS Riunione Adriatica di Sicurta SpA (The Front Comor) [2005] 2 All ER (Comm) 240.

Winter, H. (2015). The Enforcement of Foreign Arbitral Awards in Australia against Non-Signatories to the Arbitration Agreement. Arbitration International, 31, 317-347. https://doi.org/10.1093/arbint/aiv014 